\title{
LAW ENFORCEMENT ON ENVIRONMENTAL PROTECTION AND RESOURCE CONSERVATION
}

\author{
Oleh: \\ Jeanne Darc Noviayanti Manik, Wirazilmustaan \\ Faculty of Law, Universitas Bangka Belitung, Kampus Terpadu UBB Bangka, \\ Kepulauan Bangka Belitung, Indonesia \\ Corresponding Author : jeannenovi@gmail.com
}

\begin{abstract}
Conservation of natural resources is a natural resource management whose utilization is done wisely to ensure the continuity of its availability by maintaining and improving the quality of diversity and value. Conservation of natural resources and ecosystems aims to achieve the realization of the sustainability of natural resources and the equilibrium of the ecosystem so that it can better support the efforts to improve the community welfare and the quality of human life. The problem are the implementation of conservation of natural resources and its ecosystem in the region based on Act No. 5 of 1990 and law enforcement against perpetrators of the conservation of natural resources and ecosystems. The research method used is legal research using a statutory and conceptual approach. The conservation of natural resources and ecosystems is based on preserving the ability and utilization of natural resources and their ecosystem in a harmonious and balanced environment. The conservation of natural resources and ecosystems is conducted through the protection of life-supporting systems, preserving the diversity of plant and animal species along with its ecosystem and the sustainable utilization of natural resources and ecosystem.
\end{abstract}

Keywords : region, conservation, protection, environmental law, criminal policy

\section{A. PENDAHULUAN}

Sumber daya alam hayati
Indonesia dan ekosistemnya yang
mempunyai kedudukan serta peranan
penting bagi kehidupan adalah
karunia Tuhan Yang Maha Esa, oleh
karena itu perlu dikelola dan
dimanfaatkan secara lestari, selaras,
serasi dan seimbang bagi
kesejahteraan masyarakat Indonesia
pada khususnya dan umat manusia

pada umumnya, baik masa kini maupun masa depan. Pembangunan sumber daya alam hayati dan ekosistemnya pada hakikatnya adalah bagian integral dari pembangunan nasional yang berkelanjutan sebagai pengamalan Pancasila. Unsur-unsur sumber daya alam hayati dan ekosistemnya pada dasarnya saling tergantung antara satu dengan yang lainnya dan saling mempengaruhi sehingga kerusakan 
dan kepunahan salah satu unsur akan berakibat terganggunya ekosistem. Untuk menjaga agar pemanfaatan sumber daya alam hayati dapat berlangsung dengan cara sebaikbaiknya, maka diperlukan langkahlangkah konservasi sehingga sumber daya alam hayati dan ekosistemnya selalu terpelihara dan mampu mewujudkan keseimbangan serta melekat dengan pembangunan itu sendiri

Konservasi sumber daya alam hayati adalah pengelolaan sumber daya alam hayati yang pemanfaatannya dilakukan secara bijaksana untuk menjamin kesinambungan persediaannya dengan tetap memelihara dan meningkatkan kualitas keanekaragaman dan nilainya.

Ekosistem sumber daya alam hayati adalah sistem hubungan timbal balik antara unsur dalam alam, baik hayati maupun non hayati yang saling tergantung dan pengaruh mempengaruhi

Kawasan pelestarian alam adalah kawasan dengan ciri khas tertentu, baik di darat maupun di perairan yang mempunyai fungsi perlindungan sistem penyangga kehidupan, pengawetan keanekaragaman jenis tumbuhan dan satwa, serta pemanfaatan secara lestari sumber daya alam hayati dan ekosistemnya. Konservasi sumber daya alam hayati dan ekosistemnya berasaskan pelestarian kemampuan dan pemanfaatan sumber daya alam hayati dan ekosistemnya secara serasi dan seimbang.

Konservasi sumber daya alam hayati dan ekosistemnya bertujuan mengusahakan terwujudnya kelestarian sumber daya alam hayati serta keseimbangan ekosistemnya sehingga dapat lebih mendukung upaya peningkatan kesejahteraan masyarakat dan mutu kehidupan manusia. Konservasi sumber daya alam hayati dan ekosistemnya merupakan tanggung jawab dan kewajiban Pemerintah serta masyarakat. Konservasi sumber daya alam hayati dan ekosistemnya dilakukan melalui kegiatan:
a. perlindungan sistem penyangga kehidupan;
b. pengawetan keanekaragaman jenis tumbuhan dan satwa beserta ekosistemnya;


c. pemanfaatan secara lestari sumber daya alam hayati dan ekosistemnya

Pemanfaatan secara lestari sumber daya alam hayati dan ekosistemnya dilakukan melalui kegiatan:
a. pemanfaatan kondisi lingkungan kawasan pelestarian alam;
b. pemanfaatan jenis tumbuhan dan satwa liar.

Pemanfaatan kondisi lingkungan kawasan pelestarian alam dilakukan dengan tetap menjaga kelestarian fungsi kawasan. Pemanfaatan jenis tumbuhan dan satwa liar dilakukan dengan memperhatikan kelangsungan potensi, daya dukung, dan keanekaragaman jenis tumbuhan dan satwa liar. Kawasan pelestarian alam mempunyai fungsi perlindungan sistem penyangga kehidupan, pengawetan keanekaragaman jenis tumbuhan dan satwa, serta pemanfaatan secara lestari sumber daya alam hayati dan ekosistemnya terdiri dari:
a. taman nasional
b. taman hutan raya
c. taman wisata alam.

Peran serta rakyat dalam konservasi sumber daya alam hayati dan ekosistemnya diarahkan dan digerakkan oleh Pemerintah melalui berbagai kegiatan yang berdaya guna dan berhasil guna. Dalam mengembangkan peran serta rakyat Pemerintah menumbuhkan dan meningkatkan sadar konservasi sumber daya alam hayati dan ekosistemnya di kalangan rakyat melalui pendidikan dan penyuluhan. Indonesia merupakan salah satu dari tiga negara dengan kekayaan SDA hayati terbesar di dunia selain Brazil dan Zaire atau Republik Demokratik Kongo. ${ }^{1}$

Namun, keanekaragaman hayati baik di tingkat genetik, spesies maupun ekosistem ${ }^{2}$ merupakan SDA yang sangat kompleks, karena SDA ini terdapat dalam jumlah yang

\footnotetext{
1 Biodiversity Action Plan for Indonesia yang disusun dan diterbitkan oleh Bappenas tahun 1993 menyebutkan bahwa walaupun daratan Indonesia hanya 1,3\% dari daratan dunia, $10 \%$ tumbuhan berbunga, $12 \%$ mamalia, $16 \%$ reptil dan ampibi, $17 \%$ burung dan lebih dari $25 \%$ ikan air tawar dunia ada di Indonesia. Lih: Badan Perencanaan Pembangunan Nasional (Bappenas) RI, Biodiversity Action Plan for Indonesia, Jakarta: 1993, hlm. 1

2 Convention on Biological Diversity," , 5 Juni 1992, United Nations Treaty Series Vol. 1760 p. 79, Pasal 2, menyebutkan bahwa keanekaragaman merupakan variabilitas di tingkat genetik, spesies dan ekosistem
} 
terbatas

sekalipun

keanekaragamannya sangat tinggi.

Selain itu, walaupun mempunyai

sifat yang dapat memperbaharui diri atau dapat diperbaharui (renewable), sumberdaya alam hayati mempunyai sifat yang tidak dapat kembali seperti asalnya (irreversible) apabila dimanfaatkan secara berlebihan sampai pada tingkat yang melampaui kemampuannya. $^{3} \quad$ Permasalahan tersebut tercermin dari tinggginya tingkat keterancaman keanekaragaman hayati dari kepunahan. Keterancaman tersebut terutama disebabkan oleh dua faktor utama, yaitu

a. pemanfaatan keanekaragaman hayati yang berlebihan, termasuk secara ilegal; dan

b. kerusakan habitat yang disebabkan oleh konversi dan penggunaan bahanbahan berbahaya dalam pemanfaatan sumberdaya alam. Kompleksitas sumberdaya alam hayati

${ }^{3}$ Bappenas RI, Strategi dan Rencana Aksi Keanekaragaman Hayati Indonesia 20032020, (Jakarta: IBSAP Dokumen Nasional, 2003), hal. 7-16. Elaborasi lebih lanjut dalam Bab II: Keanekaragaman Hayati Demi Generasi Kini dan Mendatang tersebut bertambah dengan tingginya jumlah dan laju pertambuhan penduduk, serta rendahnya tingkat pendidikan dan sosial ekonomi di sebagian besar masyarakat Indonesia, sehingga tekanan terhadap keanekaragaman hayati semakin tinggi.

\section{B. PERMASALAHAN}

Permasalah yang muncul adalah implementasi dari UndangUndang No. 5 Tahun 1990 tentang Konservasi Sumber Daya Alam dan Ekosistemnya dan penegakan hukum terhadap pelaku tindak tindak di bidang konservasi sumber daya alam dan ekosistemnya.

\section{METODE PENELITIAN}

Metode Penelitian yang digunakan adalah metode penelitian hukum, dengan menggunakan pendekatan perundang-undangan dan pendekatan konseptual. Bahan Hukum yang digunakan adalah bahan hukum primer berupa peraturan perundang-undangan yang terkait dengan konservasi sumber daya alam dan jurnal jurnal hukum 
yang membahas dan menganalisis tentang konservasi sumber daya alam dan ekosistemnya.

\section{PEMBAHASAN}

a. The Implementation of Conservation of Natural Resources And Its Ecosystem In The Region Based on Act No. 5 of 1990

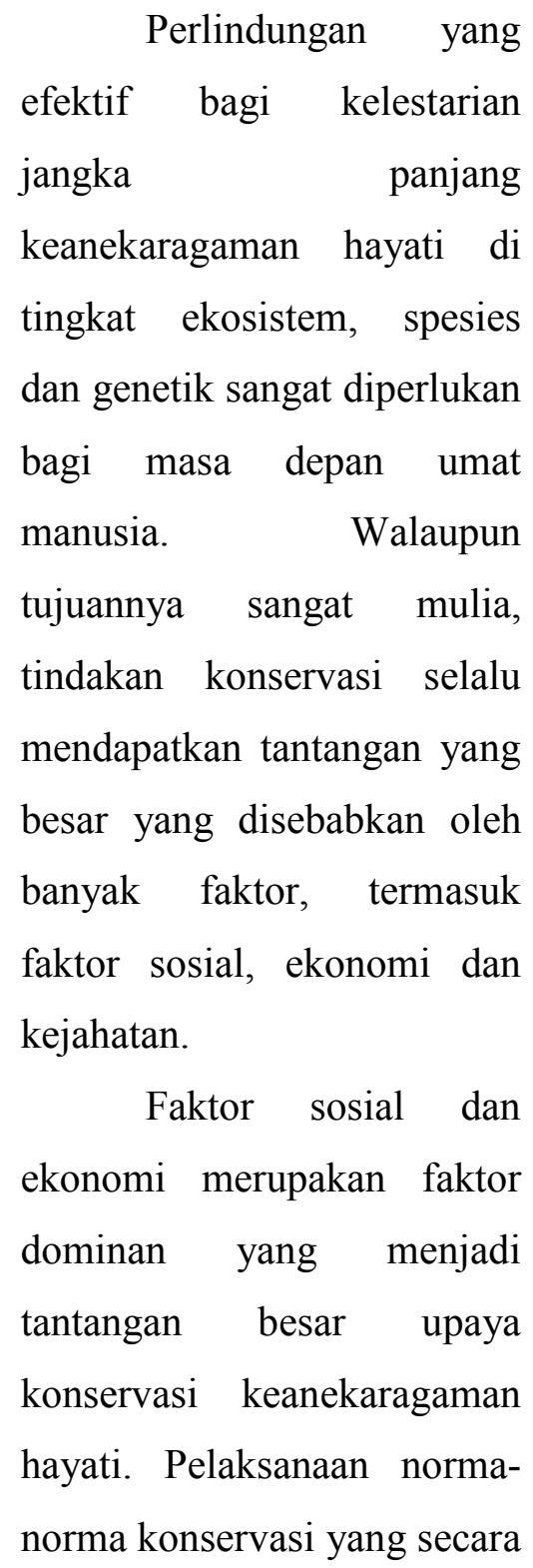

hukum mengikat banyak mengalami hambatan di negara berkembang seperti Indonesia. Asal muasal gerakan konservasi dari negara-negara barat yang sistem hukumnya lebih kuat merupakan salah satu faktor. Penerapan hukum konservasi di negara-negara berkembang banyak menimbulkan konflik, mengingat ketergantungan masyarakat akan SDA hayati masih sangat tinggi. Hal ini erat kaitannya dengan masyarakat di sekitar sumber daya yang belum terlepas dari kemiskinan. Kemiskinan menjadi kendala utama konservasi, sehingga tidak akan ada konservasi selama masih banyak masyarakat yang berada di bawah garis kemiskinan.

Ada tiga masalah yang selalu berasosiasi dengan kemiskinan dalam pengelolaan sumberdaya alam:

1. Tidak adanya hak masyarakat dan kurangnya sumberdaya; 
2. Marginalisasi dan eksploitasi secara politis;

3. Marginalisasi dan kurangnya jaring pengaman sosial dan ekonomi

Secara yuridis, saat ini hanya ada satu undangundang yang secara khusus mengatur tentang konservasi sumberdaya alam hayati yaitu UU No. 5 Tahun 1990 tentang Konservasi Sumberdaya Alam Hayati dan Ekosistemnya (selanjutnya disebut UU No. 5 Tahun 1990). UU ini, yang menggantikan beberapa produk peraturan kolonial pra-kemerdekaan, telah berumur lebih dari 20 tahun. Selama masa tersebut telah terjadi begitu banyak perubahan lingkungan strategis nasional, seperti berubahnya sistem politik dan pemerintahan dari sentralisasi ke desentralisasi dan demokratisasi, serta berubahnya peraturan perundang-undangan sektoral, maupun perubahan pada tataran global.

KSDAHE dirasakan sudah tidak efektif lagi dan banyak kelemahan untuk melindungi SDA hayati Indonesia sekarang dan di masa yang akan datang. UU ini juga tidak lagi sesuai dengan perkembangan paradigma konservasi di tingkat global maupun nasional. Oleh sebab itu, revisi UU KSDAHE dirasakan perlu untuk segera dilakukan. Ada beberapa undang-undang sektoral, misalnya perikanan, yang di dalamnya mengatur tentang konservasi sumber daya ikan ; $\quad$ undang-undang pertambangan, undangundang kehutanan dan undang-undang pengelolaan dan perlindungan hidup serta perundang-undangan lainnya. Namun, isinya masih berkonflik dengan UU KSDAHE sehingga pelaksanaan di lapangan sering menimbulkan kerancuan. Harmonisasi 
tentunya menjadi hal yang harus dilakukan. Kawasan konservasi diklasifikasikan mejadi beberapa bagian tertentu, yang dibagi dalam beberapa bentuk kawasan konservasi itu sendiri.

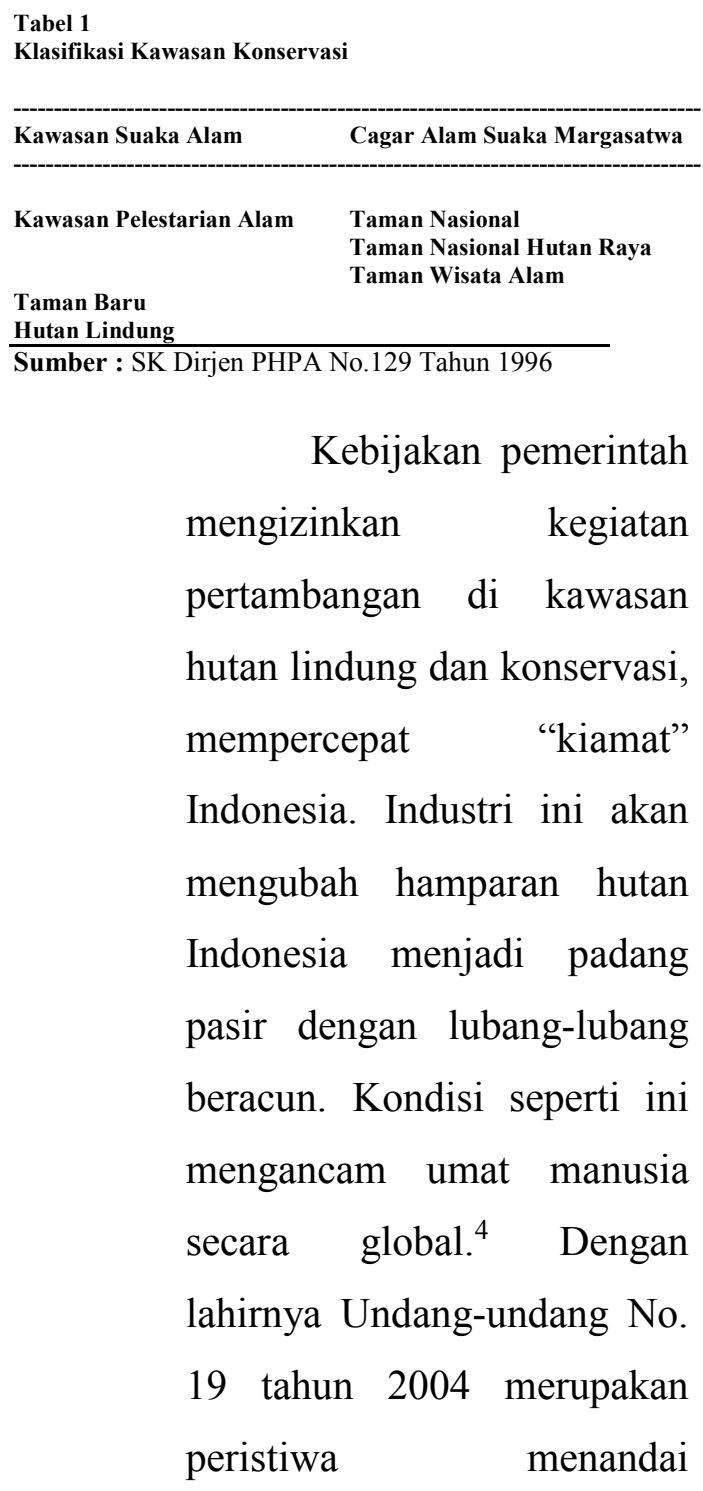

4 I Putu Gede Ardhana, Konservasi Keanekaragaman Hayati Pada Kegiatan Pertambangan Di Kawasan Hutan Di Indonesia, Jurnal Ilmu Pertanian Indonesia, Agustus 2010, Vol. 15 No.2 ISSN 0853 4217 , h. 72 dibukanya kembali untuk menambang secara terbuka ( open mining ) di kawasan hutan lindung bahkan sebagian ada yang tumpang tindih dengan kawasan konservasi. Hal tersebut berarti akan terbuka kembali iklim investasi dari sektor pertambangan. Di lain pihak peristiwa hukum tersebut mengancam pelestarian ekosistem dan pelestarian keanekaragaman hayati pada kawasan hutan yang akan ditambang mengingat kawasan hutan yang akan menjadi obyek kegiatan pertambangan termasuk wilayah yang sangat sensitif dari sisi konservasi dan telah ditunjuk fungsinya sebagai kawasan hutan lindung atau konservasi. Hutan lindung tersebut sesuai fungsinya sebagai wilayah perlindungan sistem penyangga kehidupan dan harus melindungi tata air (hidroorologis) atas kawasan di sekitarnya untuk kehidupan. Sedangkan kawasan hutan konservasi 


berfungsi melestarikan
ekosistem dan perlindungan
keanekaragaman hayati pada
kawasan tersebut seperti
termuat dalam Undang-
undang No. 5 Tahun 1990.

Di Indonesia, pengguna sumber daya alam hayati dapat dikelompokkan dalam dua kelompok besar, yaitu $:^{5}$

a. Pengguna skala kecil.

$$
\begin{aligned}
& \text { Kelompok ini } \\
& \text { menggunakan sumber } \\
& \text { daya alam secara } \\
& \text { tradisional atau semi } \\
& \text { tradisional di daerah } \\
& \text { tempat tinggal mereka } \\
& \text { untuk langsung dimakan } \\
& \text { atau ditukarkan. }
\end{aligned}
$$

${ }^{5}$ Charles Victor Barber, Meluruskan Arah Pelestarian Keanekaragaman Hayati dan Pembangunan di Indonesia/Charles Victor Barber, Suraya Afiff, Agus Purnomo, Penerjemah : Marina Malik, edisi ke-1, Jakarta: Yayasan Obor, 1997, h.22 dalam Sri Nurhayati Qodriyatun, Konservasi Sumber Dayaalam Hayati Dan Ekosistemnya Dalam Kerangka Desentralisasi, Jurnal Kajian Vol 15 No.3 September 2010 h.557 terhadap keanekaragaman hayati.

b. Pengguna skala besar, biasanya untuk pasar dunia. Penggunaan oleh kelompok ini mengubah habitat suatu kawasan, seperti mengubah hutan menjadi lahan pertanian, perkebunan, permukiman, ataupun daerah industri, yang kesemuanya didorong oleh produsen dan konsumen dari luar kawasan tersebut.

Jika mengacu UU No. 32 Tahun 2009 tentang Perlindungan dan Pengelolaan Lingkungan Hidup, melalui konsep ekoregion, UU tersebut memberikan kepastian bahwa keberadaan masyarakat di kawasan konservasi atau disekitar kawasan konservasi harus diperhatikan ketika akan dilakukan pengelolaan lingkungan hidup - termasuk ketika kegiatan penetapan suatu kawasan menjadi kawasan konservasi. Karena menurut John (dkk) secara 
teori, pengelola kawasan

konservasi dapat "berjalan sendiri" dan melindungi "kawasan tertutupnya" dari segala ancaman dan kerusakan yang tidak alami. Namun tanpa adanya dukungan dari masyarakat di sekitar kawasan tersebut, tidak ada kawasan konservasiyang akan terjamin dalam jangka panjang.

Ada beberapa halyang harus dipahami ketika suatu kawasan konservasi yang ditetapkan tumpang tindih dengan permukiman suatu kelompok masyarakat (etnik tertentu) seperti yang terjadi di taman Nasional Danau sentarum (Kalimantan barat), Taman Nasional Betung Kehirun, Taman Nasionl Gunung Leuser, Taman Nasional Bromo Tengger Semeru. Yang pertama adalah menghindari dilakukannya pemukiman kembali penduduk asli. Karena budaya asli akan tetap utuh hanya jika berada di wilayahnya sendiri. Kedua, kawasan konservasi harus cukup luas untuk menampung masyarakat setempat serta kemungkinan berkembangnya masyarakat tersebut dan untuk melindungi alamnya. Penetapan kawasah konservasi yang kurang luas hanya akan menyebabkan terjadinya proses devolusi dan degradasi ekologi bila penduduk aslitidak memiliki akses terhadap sumber daya yang mereka perlukan. Ketiga, perencanaan kawasan harus mengantisipasi pertambahan penduduk dan perubahan budaya masyarakatnya. Terakhir adalah mempekerjakan penduduk setempat sebagai penjaga kawasan. ${ }^{6}$

b. Law Enforcement Against Perpetrators of The Conservation of Natural Resources And Ecosystems

Permasalahan di atas menjadikan konservasi tidak

6 Sri Nurhayati Qodriyatun, Konservasi Sumber Daya Alam Hayati Dan Ekosistemnya Dalam Kerangka Desentralisasi, Jurnal Kajian Vol 15 No.3 September 2010. hal. 572 
efektif, karena tindakan

tindakan illegal menjadi sulit

diatasi. Hal tersebut

diperburuk dengan adanya

"petualang tanah" (free rider)

yang mengejar penggunaan

(rente) tanah murah atau

SDA murah di tanah negara

dengan menggunakan

masyarakat miskin sebagai

latar. Oleh sebab itu sistem

hukum harus dibangun sesuai

dengan kondisi setempat

yang

menempatkan

masyarakat sebagai subyek

pelaku konservasi yang

disertai dengan penegakan

hukum secara efektif. Untuk

menghindari konflik dalam

membangun konservasi,

masyarakat harus terlibat di

dalam semua aspek kegiatan

konservasi. Sebagai contoh,

IUCN merekomendasikan

konsep pengelolaan

konservasi secara kolaboratif

antara masyarakat dengan

pemerintah. ${ }^{7}$

7 Samedi, Konservasi KeaneKaragaman Hayati di Indonesia: Rekomendasi PerbaiKan Undang-Undang Konservasi, Jurnal Hukum Lingkungan Vol. 2 Issue 2, Desember 2015, hal 15
Pasal 19

(1) Setiap orang dilarang melakukan kegiatan yang dapat mengakibatkan

perubahan terhadap keutuhan kawasan suaka alam.

(2) Ketentuan

sebagaimana

dimaksud dalam ayat (1) tidak termasuk kegiatan pembinaan habitat untuk kepentingan satwa di dalam suaka margasatwa.

(3) Perubahan terhadap keutuhan kawasan suaka alam sebagaimana

dimaksud dalam ayat (1) meliputi

mengurangi,

menghilangkan fungsi dan luas kawasan suaka alam, serta menambah jenis tumbuhan dan satwa lain yang tidak asli. 
Berdasarkan Undang-Undang

Nomor 5 Tahun 1990 pada

Pasal 21 dinyatakan :

(1) Setiap orang dilarang untuk :

a. mengambil, menebang, memiliki, merusak, memusnahkan, memelihara, mengangkut, dan memperniagakan tumbuhan yang dilindungi atau bagian-bagiannya dalam keadaan hidup atau mati;

b. mengeluarkan tumbuhan yang dilindungi atau bagian-bagiannya dalam keadaan hidup atau mati dari suatu tempat di Indonesia ke tempat lain di dalam atau di luar Indonesia.

(2) Setiap orang dilarang untuk :

a. menangkap, melukai, membunuh, menyimpan, memiliki,

memelihara,

mengangkut, dan

memperniagakan

satwa yang dilindungi

dalam keadaan hidup;

b. menyimpan,

memiliki,

memelihara,

mengangkut, dan

memperniagakan

satwa yang dilindungi

dalam keadaan mati;

c. mengeluarkan satwa yang dilindungi dari suatu tempat di Indonesia ke tempat lain di dalam atau di luar Indonesia;

d. memperniagakan, menyimpan atau memiliki kulit, tubuh, atau bagian-bagian lain satwa yang dilindungi atau barang-barang yang dibuat dari bagianbagian tersebut atau mengeluarkannya dari suatu tempat di Indonesia ke tempat 
lain di dalam atau di luar Indonesia;

e. mengambil, merusak, memusnahkan,

memperniagakan, menyimpan atau memiliki telur dan atau sarang satwa yang dillindungi.
(3) Pengecualian

dari larangan menangkap, melukai, dan membunuh satwa yang dilindungi dapat pula dilakukan dalam hal oleh karena suatu sebab satwa yang dilindungi membahayakan kehidupan manusia

\section{Pasal 22}

(1) Pengecualian dari larangan sebagaimana dimaksud dalam Pasal 21 hanya dapat dilakukan untuk keperluan penelitian, ilmu pengetahuan, dan atau penyelamatan jenis tumbuhan dan satwa yang bersangkutan.

(2) Termasuk dalam penyelamatan sebagaimana dimaksud dalam ayat (1) adalah pemberian atau penukaran jenis tumbuhan dan satwa kepada pihak lain di luar negeri dengan izin Pemerintah.

\section{Pasal 33}

(1) Setiap orang dilarang melakukan kegiatan yang dapat mengakibatkan perubahan terhadap keutuhan zona inti taman nasional.

(2) Perubahan terhadap keutuhan zona inti taman nasional sebagaimana dimaksud dalam ayat (1) meliputi mengurangi, menghilangkan fungsi dan luas zona inti taman nasional, serta menambah jenis tumbuhan dan satwa lain yang tidak asli. 
(3) Setiap orang dilarang melakukan kegiatan yang tidak sesuai dengan fungsi zona pemanfaatan dan zona lain dari taman nasional, taman hutan raya, dan taman wisata alam

Sanksi Pidana bagi pelaku tindak pidana, Diatur dalam Pasal 39, menyatakan :

(1) Barang siapa dengan sengaja melakukan pelanggaran terhadap ketentuan sebagaimana dimaksud dalam Pasal 19 ayat (1) dan Pasal 33 ayat (1) dipidana dengan pidana penjara paling lama 10 (sepuluh) tahun dan denda paling banyak Rp. 200.000.000,00 (dua ratus juta rupiah).

(2) Barang siapa dengan sengaja melakukan pelanggaran terhadap ketentuan sebagaimana dimaksud dalam Pasal 21 ayat (1) dan ayat (2) serta Pasal 33 ayat (3) dipidana dengan pidana penjara paling lama 5 (lima) tahun dan denda paling banyak Rp. 100.000.000,00 (seratus juta rupiah).

(3) Barang siapa karena kelalaiannya melakukan pelanggaran terhadap ketentuan sebagaimana dimaksud dalam Pasal 19 ayat (1) dan Pasal 33 ayat (1) dipidana dengan pidana kurungan paling lama 1 (satu) tahun dan denda paling banyak Rp. 100.000.000,00 (seratus juta rupiah).

(4) Barang siapa karena kelalaiannya melakukan pelanggaran terhadap ketentuan sebagaimana dimaksud dalam Pasal 21 ayat (1) dan ayat (2) serta Pasal 33 ayat (3) dipidana dengan pidana kurungan paling lama 1 (satu) tahun dan denda paling banyak Rp. 50.000.000,00 (lima puluh juta rupiah).

(5) Tindak pidana sebagaimana dimaksud 


$$
\begin{aligned}
& \text { pada ayat (1) dan ayat (2) } \\
& \text { adalah kejahatan dan } \\
& \text { tindak pidana } \\
& \text { sebagaimana dimaksud } \\
& \text { pada ayat (3) dan ayat (4) } \\
& \text { adalah pelanggaran }
\end{aligned}
$$

Penyidikan Tindak Pidana.

Ketentuan pidana , diatur dalam Pasal 40 , menyatakan

(1) Barang siapa dengan sengaja melakukan pelanggaran terhadap ketentuan sebagaimana dimaksud dalam Pasal 19 ayat (1) dan Pasal 33 ayat (1) dipidana dengan pidana penjara paling lama 10 (sepuluh) tahun dan denda paling banyak Rp. 200.000.000,00 (dua ratus juta rupiah).

(2) Barang siapa dengan sengaja melakukan pelanggaran terhadap ketentuan sebagaimana dimaksud dalam Pasal 21 ayat (1) dan ayat (2) serta Pasal 33 ayat (3) dipidana dengan pidana penjara paling lama 5 (lima) tahun dan denda paling banyak Rp. 100.000.000,00 (seratus juta rupiah).

(3) Barang siapa karena kelalaiannya melakukan pelanggaran terhadap ketentuan sebagaimana dimaksud dalam Pasal 19 ayat (1) dan Pasal 33 ayat (1) dipidana dengan pidana kurungan paling lama 1 (satu) tahun dan denda paling banyak Rp. 100.000.000,00 (seratus juta rupiah).

(4) Barang siapa karena kelalaiannya melakukan pelanggaran terhadap ketentuan sebagaimana dimaksud dalam Pasal 21 ayat (1) dan ayat (2) serta Pasal 33 ayat (3) dipidana dengan pidana kurungan paling lama 1 (satu) tahun dan denda paling banyak Rp. 50.000.000,00 (lima puluh juta rupiah)

(5) Tindak pidana sebagaimana dimaksud pada ayat (1) dan ayat (2) adalah kejahatan dan 


\author{
tindak pidana \\ sebagaimana dimaksud \\ pada ayat (3) dan ayat (4) \\ adalah pelanggaran
}

\section{E. KESIMPULAN}

Konservasi sumber daya alam hayati dan ekosistemnya berasaskan pelestarian kemampuan dan pemanfaatan sumber daya alam hayati dan ekosistemnya secara serasi dan seimbang.

UU Nomor 5 Tahun 1990 yang telah berusia hampir 29 tahun dan yang bersifat sentralistik mengandung banyak kelemahan baik dari sisi konsep maupun kekosongan hukum apabila dikaitkan dengan perkembangan masa kini. Karena mengadopsi konsep yang dikembangkan di negara-negara barat, maka hukum konservasi di Indonesia banyak menafikan keberadaan masyarakat di dalam pengaturan dan pengelolaannya, sehingga menciptakan potensi konflik. UU KSDAHE perlu mengalami revisi materi yang signifikan dan harus harmonis dengan beberapa undang-undang lain yang terkait dengan konservasi, seperti undang-undang mengenai lingkungan hidup, penataan ruang, perikanan, dan undang-undang mengenai pesisir dan pulau-pulau kecil agar pelaksanaannya di lapangan dapat efektif

\section{F. DAFTAR PUSTAKA}

Badan Perencanaan Pembangunan Nasional (Bappenas) RI, Biodiversity Action Plan for Indonesia, Jakarta: 1993

Dhani Farisanto, Evaluasi Program Konservasi Guna , ISSN : Melestarikan Kelangsungan Ekologi Di Taman Tegallega, Jurnal Manajemen Resort dan Leisure Vol. 12, No. 2, Oktober 2015

I Putu Gede Ardhana, Konservasi Keanekaragaman Hayati Pada Kegiatan Pertambangan Di Kawasan Hutan Di Indonesia, Jurnal Ilmu Pertanian Indonesia, Agustus 2010, Vol. 15 No.2 ISSN 0853 - 4217

Indonesian Center fot Environmental Law, Jurnal Hukum Lingkungan Indonesia, Volume 04, Issue 2, Febuari 2018, ISSN 2355-1305, diterbtkan oleh (ICEL), Jakarta

Kistantia Elok Mumpuni, Herawati Susilo, Fatchur Rohman, Peran Masyarakat dalam Upaya Konservasi (The Role of Society Toward Concervation), Universitas Negeri Malang, Seminar Nasional XII Pendidikan Biologi FKIP UNS 2015 
Manuel Boissiere, Miriam van Heist et.all , Journal of Tropical Ethnobiology Vol I (2) : 76 95, Pentingnya Sumberdaya Alam bagi Masyarakat Lokal di Daerah Aliran Sungai Mamberamo, Papua, dan Implikasinya bagi Konservasi, Department of Sociology \& Anthropology, University of Puget Sound, 1500 North Warner St., CMB\#1092, Tacoma, WA 98416

Samedi, Konservasi KeaneKaragaman Hayati di Indonesia: Rekomendasi Perbaikan Undang-Undang Konservasi, Jurnal Hukum Lingkungan Vol. 2 Issue 2, Desember, 2015

Suwari Akhmaddhian, Peran Pemerintah Daerah Dalam Mewujudkan Hutan Konservasi Berdasarkan Undang-Undang Nomor 41 Tahun 1999 Tentang Kehutanan (Studi di Kabupaten Kuningan), Fakultas Hukum Universitas Kuningan E-mail : suwariakhmaddhian@gmail.co $\underline{m}$, Jurnal Dinamika Hukum Vol. 13 No. 3 September 2013

Undang-Undang Dasar Negara Republik Indonesia Tahun 1945

Undang-undang Republik Indonesia Nomor 5 Tahun 1990 tentang Konservasi Sumber Daya Alam Hayati dan Ekosistemnya 